This is an Accepted Manuscript of an article published by Edinburgh University Press in Journal of British Cinema

and Television. The Version of Record is available online at:

http://www.euppublishing.com/doi/abs/10.3366/jbetv.2021.0554

\title{
A world on his shoulders: Nat Cohen, Anglo-EMI and the British film industry
}

\begin{abstract}
:
Despite being one of the most significant players in the British film industry of the 1960 s and 1970s, Nat Cohen remains a curiously neglected figure in histories of those eras. At Anglo-Amalgamated he oversaw a varied slate of production, from B-movies and cheap programmers to box office successes like Ken Loach's Poor Cow (1968). He greenlit some of the biggest successes of the sixties, including New Wave dramas (Billy Liar, A Kind of Loving), pop musicals (Catch Us If You Can) and horror films now widely considered to be classics of British cinema (Peeping Tom). After Anglo-Amalgamated was acquired as part of EMI's takeover of ABPC, Cohen headed Anglo-EMI, where his business acumen and shrewd commercial instincts led to his being dubbed 'King Cohen' by the press and widely recognized as one of the most powerful men in the British film industry. Drawing on recent scholarly work on the role of the producer (Spicer: 2013), this article will explore links between Anglo-ABPC and EMI through the lens of Cohen's career and distinctive 'movie mogul' persona.
\end{abstract}

Keywords: Nat Cohen; British film industry; cinema; producer; mogul; EMI; Bryan Forbes

\section{Introduction}

The Anglo-Amalgamated logo would be familiar to almost anyone who was a cinemagoer in the 1960s, and although the exact iconography changed over the years, the specifics remained the same: a chiselled figure of Atlas holding aloft a metal sculpture of the Earth inscribed with the names of the company's partners, Nat Cohen and Stuart Levy. In a way the logo would prove prophetic, as by the mid-1970s it seemed that Cohen was a central figure in supporting what remained of the British film industry after years of recession. In Hollywood England, Alexander Walker's irreverent, comprehensive journalistic overview of the 1960s British film industry, Nat Cohen receives scant mention, whereas Bryan Forbes, Cohen's rival Head of Production at EMI from 1969-71, receives multiple pages of attention (though granted, Forbes's acting, directing and producing career meant that he was never far from the public eye in the sixties). But aside from one candid interview with the Guardian in 1973 - a 
full two pages are devoted to Cohen-interviews with the producer are difficult to find (Murari 1973: 9). How can the activities of a man with so much power and responsibility in the British film industry have been so seldom documented in trade press, biography, and academic scholarship? This article will draw on the small number of published and unpublished sources that are available, contextualising this material with historical research to sketch a picture of Cohen's involvement in the British film industry over three decades. Cohen experienced the film industry at all levels of production, distribution and exhibition, beginning as an exhibitor of a small chain of cinemas, then a distributor of cheap rentals and ' $\mathrm{B}$ ' pictures, a producer of second features, horror and exploitation and later a producer of some of the most culturally important films of the 1960s (including A Kind of Loving [1962] Billy Liar [1963], Darling [1965] and Poor Cow [1967]). In the later stages of his career Cohen was head of the most successful film studio operating in Britain, and he was by extension the most influential man in the film industry. His career saw the development of the 'quota quickies', the death of the British 'B' movie, the rise of the 'runaway' production and the Hollywood financial boom and the bitter dregs that were left behind after American studios withdrew funding in the late 1960s. More importantly, Cohen's career trajectory is also a story of industry monopoly, and this article will consider Cohen's role at EMI as a consequence of a beleaguered national industry pared down to the point that control over production, distribution and exhibition could be held by a few companies, with a disproportionate amount of power placed in the hands of one executive.

Early days and the rise of Anglo-Amalgamated

Prior to developing his own exhibition interests at the age of 25, Nat Cohen had been tangentially linked to the film business via family connections. His father had been a partner in a cinema in London's East End, while in 1931 Cohen married Ailsey Defries, the daughter of Harry Defries, chairman of a small producer-distributor named the Sterling Film Co. that managed an annual production slate of around 6 films per year (Bioscope 1931). In 1932 Cohen bought the Savoy, a 650-seat cinema, and within a few years he had built up a modest circuit of three London cinemas with an additional four in the provinces. His first foray into distribution was with the films of the American producer Hal Roach (who was most famous for the Laurel and Hardy series of comedies). It is not easy to piece together Cohen's activities in the 1930s and 1940s, although in one interview Cohen mentions staying in England during the war to make military films while his wife and daughter moved abroad to live with good friend Samuel Goldwyn (Murari 1973: 9). During the war Cohen also moved 
into production, forming a company with partner Stuart Levy in 1942, initially producing films under the Cohen-Levy label before forming Anglo Amalgamated (Rubinstein 2011: 171). ${ }^{1}$ Anglo started small, with the production of featurettes about dogs and horses (titles included Spotlight on Dogs) which were distributed by rental companies like ABFD and Renown. Cohen and Levy soon realised that they could cut costs by going into distribution themselves (and thereby keeping the revenue they would normally pay out to a distribution company), and in 1950 they began acquiring re-issues and second features. In 1952 they formed a relationship with Merton Park Studios and moved into production with the second feature Street of Shadows (1953) which starred Cesar Romero and had some American studio involvement (Ryder 2007: 55).

Anglo was one of many renters in the 1950s, like New Realm and Renown, who bought and sold second features in the UK and American markets, often buying up older releases and selling them as fodder for the bottom half of the cinema programme. Cutting together television episodes to make a feature film was a common practice at the time among smaller distributors, although Cohen notes that he was one of the first producers to make and sell films to American television (Murari 1973: 9). Working with American actors like Romero, Faith Domergue and Zachary Scott meant that Anglo could tap into both UK and American markets, and Cohen and Levy were especially keen to forge relationships with smaller Hollywood studios to ensure a steady supply of product for this reason (Mann 2007: 129). One key relationship was with the American Releasing Corp., later American International Pictures, a company which developed talented exploitation producers, most notably Roger Corman. Through AIP Anglo acquired a number of cheap pictures aimed at teen audiences that could easily be tacked on to fill out supporting programmes for smaller cinema chains, films like The Fast and the Furious (1956) (which had a full circuit release) Cat Girl (1957), the unofficial remake of RKO's surprise breakout hit Cat People (1942) and science fiction thriller The Amazing Colossal Man (1957). In the best tradition of the exploitation film sector, AIP's modus operandi was to invent titles for films and later assign producers to write the stories to fit (Ryder 2007: 58). Their mix of teen films and monster movies may not always have appealed to Rank and ABC (AIP did not reportedly have the best reputation with

\footnotetext{
${ }^{1}$ Some sources list the incorporation date of Anglo-Amalgamated as 1942 and others 1945. 1942 is the date listed in The British Film and Television Year Book 1957-8 and William D. Rubinstein, et al (eds.) The Palgrave Dictionary of Anglo-Jewish History, Palgrave Macmillan, 2011, p.171
} 
the major circuits), but smaller exhibition chains such as Essoldo were keen to acquire them (Ibid.: 58).

By the late 1950s Anglo had grown from small distributor-renter to a profitable production company that could be relied upon to supply the major circuits with consistently high quality second feature product. Their Scotland Yard and Scales of Justice shorts were dependable, formulaic crime dramas which could easily be slotted in to cinema programmes, while their series of one-hour second features based on Edgar Wallace short stories made by Jack Greenwood at Merton Park were some of the most critically acclaimed 'B' pictures that played on the ABC circuit. Many of these films served a dual function and could be distributed to cinemas in the UK and sold to television networks like ABC (the American Broadcasting Company). The Edgar Wallace crime thrillers in particular were hugely successful, and dubbed versions were produced for companies in France, Italy and Germany, while some distributors would occasionally cut two of the films together to make one ' $\mathrm{A}$ ' feature (Kine Weekly 1962). Recognising the need for a stable production base, Cohen and Levy had invested heavily in Merton Park Studios, adding 8000 square feet of studio space in 1958 (Mann 2007: 130). For producers with access to a studio and interests in both 'A' and ' $\mathrm{B}$ ' picture production, shorts and second features provided a useful way of maximising the empty space between shooting schedules as well as providing a consistent supply of work for technicians (Mayne 2017).

In the post-war period the double-feature package was still the norm on most major and minor cinema circuits and there was a market for shorts and second-feature product, but by the end of the 1950s the rising cost of production meant that second features were no longer desirable or profitable, as second features were sold for a fixed fee and thus not eligible for box office returns. By 1960, many small distributors had gone bust due to the waning popularity of the double bill, but by this point Anglo had moved into the production of profitable 'A' features. There were a number of turning points in the 1950s which served to gradually propel Anglo to their position as a 'key player' by the early 1960s. The first was The Sleeping Tiger (1954), a film noir by the blacklisted American director Joseph Losey, then in hiding in the UK and working under the pseudonym Victor Hanbury. This was Losey's first British film and the first of a series of collaborations with the actor Dirk Bogarde, who would soon become a household name following the hugely successful Ralph Thomas and Betty Box comedy Doctor in the House (1954). The film represented an important moment for Anglo mainly because it was the first time the company had secured 
top billing on a major circuit release (Ryder 2007: 58). The next key success for Anglo was The Tommy Steele Story (1957), a coming-of-age musical charting the young singer's rise to fame and a forerunner of the later Beatles films. The film was a hit with teenage audiences and was followed up with The Duke Wore Jeans in 1958. In his autobiography Steele describes Cohen and Levy as 'quite different from that other British film mogul, J. Arthur Rank. Where Rank was C. Aubrey Smith, Cohen and Levy were Abbot and Costello' (Steele 2006: 270). He remembers his first meeting with the partners as an encounter with an amusing and slightly unhinged double-act:

Cohen: 'We want to do a big musical.'

Levy: 'A small documentary!'

Cohen: 'With Technicolor, stereophonic sound.'

Levy: 'A black-and-white talkie.'

Cohen: 'With plenty of time to rehearse and prepare and shoot a masterpiece.'

Levy: 'Four weeks maximum.' (Ibid., 271).

There was, Steele noted, 'a degree of madness' about two the men who were prepared to gamble large amounts on an untried proposition. The most profound success for the company was a gamble that would pay considerable dividends for almost a decade - the hugely successful Carry On... series of films. Carry on Sergeant was a box office hit in 1958 and Carry On Nurse was reported to be the most successful film at the British box office in 1959 (and Cohen was ready to offer $£ 10,000$ to anyone who could prove otherwise) with subsequent instalments reaching the box office top ten in the years following (Daily Express 1961). Much has been written about the series and this article will not re-tread familiar ground, but it is worth noting that the films, initially made for between $£ 70-£ 100,000$ were consistently successful and returned profit for Anglo many times over. They were also consistently unpopular with the critics from the beginning. Monthly Film Bulletin dubbed Carry On Nurse 'A somewhat stale farce, mixing slapstick, caricature and crudely anatomical humour, puts life in a public hospital ward into the same cheerlessly rollicking category as the barrack-room' (Monthly Film Bulletin: 1959: 45). Still, the early success of the Carry On franchise was enough to earn Cohen the moniker of 'Cinema Tycoon' in a special feature on 
film producers in The Times in 1961. Cohen would continue to prove that low-budget comedies aimed at the domestic market could turn a sizeable profit, and later during his time at EMI he would employ a similar formula with the low-budget television sitcom adaptations On the Buses (1971) Steptoe and Son (1972) and The Likely Lads (1976).

Anglo's forays into horror are also well-documented, with their first film Horrors of the Black Museum (1959), produced by Jack Greenwood in partnership with AIP and the American 'B' movie producer Herman Cohen. This was the first of three horror films (the others were Circus of Horrors and Peeping Tom, both 1960) produced by Anglo that were later nicknamed 'the Sadean Trilogy' by David Pirie because although all three films were made with different crew and financiers, they were notable for their focus on sadism and sexual violence. The controversial potential of Peeping Tom, a voyeuristic tale about a killer who attacks women and then films them at the point of death, slipped by the censor John Trevelyan, who did not pick up on what made the film different from the other 'Sadean' films that Anglo had distributed. Peeping Tom's point-of-view shots, a cinematic device ubiquitous in later slasher films but unusual for the time, positioned the viewer as killer and made the audience complicit in the protagonist's crimes. Coupled with its quasi-pornographic framing and 'snuff' themes the overall effect was unsettling. Widely lauded as one of the most disgusting films many critics had ever seen, the response to Peeping Tom would have been a gift to any distributor specialising in exploitation product. But whereas a few years earlier Anglo may have effectively exploited Peeping Tom film on the smaller circuits, unfortunately ABPC did not want to be associated with the film and Cohen capitulated to pressure to pull it from the ABC circuit (Walker 2000: 17).

By the mid-1960s independent cinemas were closing around the country which meant that Anglo reduced their number of sales offices in the provinces and instead began to focus on production (Ryder 2007: 71). Table 1 offers a snapshot of UK distributors in the 1960s and shows Anglo emerging as one of the key players in the distribution of ' $A$ ' features in this decade (the table does not include the 47 Edgar Wallace 'B' features produced by Jack Greenwood at Merton Park, but it is worth noting that in the early 1960s Anglo was the only remaining major player in second feature production). Anglo began to form a closer relationship with APBC when it bought 50\% of Anglo in 1962 and following this acquisition Anglo's distribution was increasingly handled by Warner-Pathe. Duncan Petrie writes that in the 1960s 'Anglo's films only intermittently aspired to traditional British markers of quality and good taste' (Farmer et al 2019: 49). Anglo did not specialise in any particular genre, and 
it is perhaps for this reason that the company does not seem to have developed a distinct identity in histories of British cinema. Hammer is often associated with gothic horror despite the variety of their production slate throughout the 1960s, and Rank is often associated with low-budget British comedies, and while Anglo is often mentioned in the same breath as the Carry On... series the company's slate was not easily categorizable. Anglo was involved in some of the key cultural milestones of 1960s British cinema, including A Kind of Loving (1962), Billy Liar (1963), Darling (1965) and Poor Cow (1967), but their association with more critically-acclaimed productions was, as Petrie notes, intermittent (Farmer et al 2019: 49). Anglo saw out the decade in a strong position economically if not personally: the death of Stuart Levy in 1967 was a blow for both Cohen and the company. That same year Anglo, by then an extremely profitable outfit, became $74 \%$ owned by ABPC. When ABPC was acquired by EMI in 1969, Anglo became a subsidiary of the largest film company in Britain.

Table 1: British feature films over 72 minutes distributed in the UK, 1960-1969²

\begin{tabular}{|l|r|}
\hline Rank Film Distributors & 105 \\
\hline Columbia & 85 \\
\hline Warner-Pathe Distributors & 84 \\
\hline United Artists & 70 \\
\hline Anglo-Amalgamated & 56 \\
\hline British Lion & 44 \\
\hline 20th Century Fox & 43 \\
\hline Paramount & 40 \\
\hline MGM & 35 \\
\hline Bryanston & 21 \\
\hline MGM British & 21 \\
\hline Universal International & 14 \\
\hline Walt Disney & 13 \\
\hline Tigon & 10 \\
\hline Compton & 10 \\
\hline
\end{tabular}

*Certified British by the Board of Trade

EMI later bought the remaining shares in the company, now re-named Anglo-EMI. Bernard Delfont appointed Bryan Forbes as head of EMI's film production division, with Cohen supervising as head of his own separate division. A full account of Forbes's short tenure at EMI is provided by Paul Moody (2018) Forbes (1992) and Walker (1986). Moody notes that by keeping Bryan Forbes and Nat Cohen as production heads Delfont 'opened up a clear rivalry between the two which would fester over the next two years and was ultimately

\footnotetext{
${ }^{2}$ Data taken from a database of 1960s British film releases created for the AHRC-Funded project Transformation and Tradition in Sixties British Cinema (2015-2018).
} 
unsustainable' (Moody 2018: 14). At EMI Forbes's ambitious production plans were undermined by cumbersome administrative processes, hostile board members and lack of support from management. Forbes had access to a considerable revolving fund which would, he noted, have been useful 'if it had revolved' (Walker 2005: 114). To make matters worse Cohen, who had access to a smaller fund, produced a series of modestly-budgeted films that were commercially (if not always critically) successful. Of the top ten box office films in 1970, five of these were EMI films and three of those were produced by Cohen's outfit (Moody 2018: 80).

'He does not make artistic films': Cohen as a producer

Romantic ideas about individual creativity were crucial to the establishment of Film Studies as an academic discipline in the 1960s and 1970s, when the history of Hollywood cinema was reconceptualised with an emphasis on the works of so-called great directors. And although film scholarship has since grown to encompass nuanced theories of creative labour and industrial practice in the creative industries, the spectre of the 'auteur' lingers. Several recent works (Spicer and McKenna: 2013; Spicer et al: 2014) have offered new ways of thinking about the historical role of the producer as an intermediary in the creative, cultural and economic context of film production. In the context of British cinema history, Spicer has foregrounded the mutable nature of the 'producer' throughout long periods of industrial and structural change. He argues that in general we might think about three distinct kinds of production role which have existed throughout the history of British cinema, or three 'types' of producer: the 'moguls' who, like Korda or Balcon, ran big companies and tended to contract producers to make films; the 'independents' or 'middle-tier' producers who (like Julian Wintle of Independent Artists) might contract producers and also produce their own films; and finally the 'artisans' who (like Joseph Janni) produced low budget independent films on an ad-hoc basis (Spicer 2017). The fluidity of these categories are such that many producers may have occupied two or more of these roles. Forbes arguably had experience of being an 'artisan' in the sixties and a 'mogul' during his short tenure at EMI, while for much of his career Cohen operated as a 'middle-tier' producer who preferred to work from the office rather than on the studio floor. Cohen, rarely credited with creative decision making, is often seen as 'the force behind' a number of key critical and commercial successes. 
Alexander Walker's description of Cohen as 'a more urbane version of the one-man-bands who used to boss the studios in Hollywood's heyday of the movie moguls' is much in line with how he is described by his contemporaries (Walker 2005: 457). The producer Sandy Leiberson describes him as 'a throw-back to the old days of Jack Warner, Harry Cohen, etc...he was fantastic, but he was the last of a breed' (Barber 2009: 383). Moody notes that Cohen's reputation as a producer who could anticipate popular demand had branded him with the archetype of 'the crass, money-oriented studio head that was also more than a little indebted to traditional anti-Semitic stereotypes that were all too often flung in the direction of the Jewish Cohen and Delfont' (Moody 2018: 84). Cohen was all too aware of this public persona, and one can detect a hint of sarcasm in statements like 'the thing is not to go in for being artistic' and 'I wouldn't call The Apartment an artistic film, and you know how much money that film made' (Daily Express 1961). There is also evidence that Cohen fought against this narrative. Alexander Walker notes that in a personal interview Cohen was 'at pains' to stress that the Joseph Losey film The Go-Between had been part of his, not Forbes, slate (though Walker stresses that on that same slate was Percy (1971), a film about a man who undergoes a penis transplant) (Walker 1985: 114). In a 1973 interview with the Guardian (oft-referenced in this article, but useful for the level of detail it provides) Cohen is 'sensitive on the subject of quality' and keen to highlight his involvement in A Kind of Loving, Poor Cow, Darling and Billy Liar as he is to point out that $95 \%$ of his films turned a profit (Murari 1973: 9). The overwhelming sense one gets from journalistic coverage of film professionals is that there are only two types of producer: vulgarians who are obsessed with the bottom line, and creative producers who are not.

Cohen was a racehorse owner as well as a film producer, and far more column inches have been devoted to Cohen's racing interests (his horse Kilmore won the Grand National in 1962) than to his filmmaking activities. This is perhaps why Cohen is often referred to as a 'gambler', and while this was undoubtedly the case, his caricature as a money-man obsessed exclusively with the bottom line owes much to cultural stereotypes of the producer as well as a tendency to view cultural production in terms of a creative/commercial binary. Cohen was also keen to work with Ken Loach, whom he described as a 'genius', and he continued to develop this relationship at EMI, backing Family Life (1971), a remake of Loach's earlier Wednesday Play In Two Minds (1967) (Ibid.: 9). Less well-documented are his interests in theatre. In 1962, Cohen made a successful bid to take over the lease of The Arts theatre, an important hub in the cultural life of the London stage. Though theatre aficionados were 
worried that Cohen would turn the theatre into a cinema, his aim appears to have been to develop closer ties between the film and theatre industries, and he stated that his intention was to develop 'the first venture in this country where a theatre will be used as a talent source for the wider and more universal medium of film. This will include all those who contribute to the Theatre (sic), writers, actors, directors and designers' (The Stage 1962).

In his autobiography Forbes describes encountering Cohen on just two occasions, once at an EMI board meeting and once for a private drink as Forbes was leaving the company. Forbes's brief description of Cohen as 'one of the fixtures of Wardour Street' accords with characterisations by historians (Harper and Porter 2012: 117; Petrie 2019: 49; Walker 1986) in that Cohen is often seen as an establishment figure who was failing to adapt to the structural and creative changes that had been taking place in the industry from the early 1960s. As a working-class actor, director, producer and writer who had moved apace with cultural change Forbes felt effectively stifled at EMI by members of the old guard whom he thought viewed him as a radical. Forbes was a cultural intermediary in a space occupied by colleagues united by markers of taste, culture, dress, and experiences of the industry that were different from his own (Forbes 1992). Forbes writes: 'I was once asked by the chief executive why I came to board meetings dressed like a cowboy, a remark prompted by the fact that I was wearing a perfectly ordinary safari suit' (Ibid.: 30), an interaction that speaks volumes sociologically. Forbes recounts pitching The Tales of Beatrix Potter to the EMI Board and being met with confusion from Nat Cohen ('Who's Beatrix Potter?') and ignorance from another board member ('Ballet films are shit') (Ibid.: 1992). Though Cohen never penned his own memoirs one can gather from the few journalistic interviews in existence that his experience of EMI was very different; Cohen appears to have had access to a fund, an impressive amount of autonomy and, crucially, the support of the board. Forbes's account hints at what is so often difficult to evidence historically based on archive sources, interviews and second-hand accounts; that to theorise the role of the producer effectively we must go beyond economics and 'creativity' and think about how the creative labour of the producer reacts to (and against) the complex hierarchies of class and distinction that have always characterised the creative and cultural industries.

A 'one-man band': monopolies and power 
In 1948 Hollywood studios were forced to divest themselves of their exhibition interests, and the ensuing loss of vertical control over production, distribution and exhibition meant that studios now faced immense risk. This risk was in part offset by a series of acquisitions and mergers (beginning in the 1950s with MCA's acquisition of Universal) which saw Hollywood studios become subsidiaries of larger international corporations. This was mutually advantageous: large conglomerates were interested in studio real estate and pre-48 film catalogues, and in return, studios would be guaranteed greater financial security. In Britain, the industry was smaller and structured differently but the British film industry had no Paramount Decree to contend with. The only challenge to the monopoly enjoyed by Rank and $\mathrm{ABC}$ was the Monopolies Commission of 1966 which recognised the consequences of the stranglehold of two companies on the industry and suggested a number of recommendations which ultimately came to nothing. Cohen was well aware of the advantages of his position compared with that of a Hollywood studio head, stating that after 1948 'studios were cut off from the public so that they weren't aware that tastes were changing. Through Anglo-EMI distribution and the EMI cinemas I'm constantly aware of what the public wants to see' (Murari 1973: 9).

Even prior to the Paramount decree, few Hollywood studio heads would have wielded as much power as Cohen did in 1973, relatively speaking. The consolidation of power in the hands of EMI was a consequence of a process of restructuring that had taken place in Britain across two decades. On the production side, in the 1950s rising costs had driven out the low-budget and supporting features market, and this had in turn led to the closure of smaller producers, renters and distributors. The independent exhibition sector had also contracted due to several factors including the decline of the supporting features, changing trends in cultural consumption and the lack of an effective 'third national' circuit to challenge the two major circuits, Rank and ABC, which by the 1960s reigned supreme. One of the more damning findings of the Monopolies Commission of 1966 had been the revelation (unsurprising to independent producers) that if a film was not released on one of the two major circuits, turning a profit in the domestic market was a near-impossibility. By the mid-1960s the key players in production and distribution were Anglo-Amalgamated, British Lion, Rank and ABPC (with the latter two companies also the key players in exhibition). The industry had prospered as a result of American finance, which in the 1960s accounted for somewhere between $75-80 \%$ of all production funding, but with the wholesale withdrawal of Hollywood 
studio funding in the late 1960s recession was an inevitability. US investment in British films fell from $£ 31.2 \mathrm{~m}$ in 1969 to $£ 17.5 \mathrm{~m}$ in 1970 and just $£ 8.3 \mathrm{~m}$ in 1971 (Walker 1985: 115).

The acquisition of ABPC and Anglo had left just three key players by the mid-1970s: British Lion, EMI and Rank, and Rank had for some time been focused on exhibition rather than production. This left Cohen in charge of the largest production fund in the UK and head of the company which owned the country's largest exhibition circuit. If Cohen was troubled by his unchallenged position, this was primarily because he longed for competition. It seems likely that filmmakers were troubled by the lack of diverse sources of funding in a struggling industry. Ken Loach enjoyed working with Cohen and appreciated his hands-off approach, but he voiced opposition to Cohen's influence over the industry:

He has too much control over it. Do you know how he works? Every morning he studies the box office receipts and sees which films are making money and concentrates on those. So, slowly, the spectrum is becoming narrower and narrower. (Murari 1973: 9).

The speed of decision-making in a one-man operation was something that had worked for Cohen in his earlier days at Anglo-Amalgamated and in his later years at EMI. Cohen had the freedom to make decisions 'on a combination of the project and the individual who brings it to me' (Walker 1986: 111). This was reportedly how Cohen had made the decision to back Joseph Janni with A Kind of Loving and Billy Liar; Janni, virtually a stranger to Cohen, had a proven track record at Rank as a successful producer and Cohen sensed an appetite among audiences for films that reflected a level of realism, and enacted the decision right away (Ibid., 111). Cohen's negotiating skills were also crucial in securing the rights to Murder on the Orient Express (1974), and ambitious project which signalled EMI's move toward higher budget, more international product. (Moody, 2018: 137).

Changes in the exhibition sector by the early 1970s had almost obliterated the smaller independent circuits on which Anglo used to distribute second feature product in the 1950s, leaving the number of cinemas owned by Rank and EMI (ABPC) virtually unchanged. Ironically, the number of licensed cinema screens operating in the UK was actually increasing for the first time in decades owing to the fact that major studios were converting cinemas into multi-screen outfits (a move which anticipated the multiplex boom of the 1980s). 
Table 2: Cinemas owned by major circuits in Britain ${ }^{3}$

\begin{tabular}{|l|l|l|l|}
\hline Company & $\mathbf{1 9 6 6}$ & $\mathbf{1 9 7 2}$ & Total \\
\hline ABC/EMI & 267 & 256 & $\mathbf{- 1 1}$ \\
\hline Rank & 330 & 234 & $\mathbf{- 9 6}$ \\
\hline Classic & 29 & - & - \\
\hline Star & 60 & 98 & +38 \\
\hline Essoldo & 51 & - & - \\
\hline Classic/Essoldo/Tigon & - & 130 & - \\
\hline Total & 737 & 718 & $\mathbf{- 1 9}$ \\
\hline Other cinemas & 1276 & 801 & $\mathbf{- 4 7 5}$ \\
\hline Total UK cinemas & 2013 & 1519 & $\mathbf{- 4 9 4}$ \\
\hline
\end{tabular}

For all Cohen's confidence in predicting what audiences wanted, was he telling the same old stories and failing to engage an increasingly fragmented cinema audience? Sian Barber argues that in addition to the collapse of conglomerates the decade also saw the 'polarisation of the industry into groups and factions, and of the mass audience into smaller, more discerning taste communities' adding that 'one of the principal problems for the industry was the refusal of key personnel, including Nat Cohen and Lew Grade, to accept the disappearance of the mass audience and to offer product for smaller audiences' (Barber 2009: 85 ). According to Spicer, Cohen's production policies in the 1970 s were characterised by circumspection rather than enlightened risk, investing in safe subjects such as television spin-offs including On the Buses (1971) and its sequels.' (Spicer 2017: 12)

\section{Conclusion}

Accounts of Cohen's modus operandi and film production policies are riddled with contradictions. Cohen is by his own account a producer who was able to action decisions quickly, adapting and anticipating changing audience tastes, and Anglo's production slate would certainly support this theory: Cohen and Levy had anticipated a number of highly profitable trends including pop-music films, the Carry On comedies and the films of the British New Wave. On the other hand, Cohen is also depicted as a member of the old guard, an industry 'fixture' who, in the 1970s, failed to anticipate the changing exhibition sector and the fragmentation of the mass audience. Cohen's persona is that of the money-man, the producer who follows audience tastes with little regard for cultural worth or relevance (a

\footnotetext{
${ }^{3}$ Data sourced from TNA, FV60/66, Monopolies Commission: Action Taken on Report on Cinema Films, table originally published in Farmer, R., Mayne, L., Petrie, D. and Williams, M. (2019), Transformation and Tradition in Sixties British Cinema, Edinburgh: Edinburgh University Press. pp. 119-137.
} 
stereotype that owes much to the myth of a creative/commercial binary in film that is both long debunked and annoyingly persistent). But perhaps the story of his career reveals less about the inscrutable figure of Nat Cohen than it does about the changing structure of the film industry in the 1960s and 1970s. Cohen's rise to Head of Production at EMI is both a cautionary tale and an example of how power was consolidated in a film industry that lacked infrastructure and was for decades entirely reliant on external funding. The rivalry between Cohen and Forbes, two very different producers, might also offer a snapshot, however brief, of how the role of the producer is embedded in the complex social and cultural hierarchies of the film industry of the early 1970 s.

\section{References}

Barber, S. (2009) 1970s British Film: Capital, Culture and Creativity, University of Portsmouth: Unpublished Doctoral Thesis.

Daily Express (1961), 24 March.

Farmer, R., Mayne, L., Petrie, D. and Williams, M. (2019), Transformation and Tradition in Sixties British Cinema, Edinburgh: Edinburgh University Press.

Forbes, B. (1992), A Divided Life, London: William Heinemann.

Harper, S. and Smith. J (2012), British Film Culture of the 1970s: The Boundaries of Pleasure, Edinburgh: Edinburgh University Press.

Kine Weekly (1962), January 25.

Mann, D. (2007), An Industrial and Cultural History of Selected British Crime Supporting Features and Filmed Television Series 1946-1964, University of the West of England: Unpublished doctoral thesis.

Mayne, L. (2017) Whatever happened to the British 'B' movie? Micro-budget film-making and the death of the one-hour supporting feature in the early 1960s, Historical Journal of Film, Radio and Television, 37:3, 559-576, DOI: 10.1080/01439685.2016.1220765

Monthly Film Bulletin (1959), Vol. 26, Iss. 300 London.

Moody, P (2018), EMI Films and the Limits of British Cinema, Cham: Palgrave Macmillan. Murari, T. (1973), "Nat King Cohen', the Guardian, 17 November.

Rubinstein, W. D. et al (eds.) The Palgrave Dictionary of Anglo-Jewish History, Palgrave Macmillan. 
Ryder, D (2007), Making it in Wardour Street, Leeds: Cinemuseum Publishing.

Spicer, A. H. (2017). 'Producers and Moguls, 1930-1980' in I. Hunter, L. Porter, \& J. Smith (Eds.), The Routledge Companion to British Cinema History, Taylor \& Francis (Routledge).

Steele, T (2007), Bermondsey Boy : Memories of a Forgotten World, London: Penguin.

The Bioscope (1931), 18 February.

The Stage and Television Today (1962), March 15.

Walker, A (2000), 'Don't Blame the Critics', the Guardian, March 17, 2000.

Walker, A (2005), National Heroes, British Cinema in the Seventies and Eighties, Orion.

Walker, A. (1986), Hollywood, England: The British Film Industry in the Sixties, London:

Harrap.

Notes 